KS. JAN KOWALSKI

\title{
STOLICA APOSTOLSKA WOBEC ORGANIZACJI MIĘDZYNARODOWYCH ZA PONTYFIKATU PIUSA XII
}

Za pontyfikatu Piusa XII działalność międzynarodowa Stolicy Apostolskiej przyjęła szerokie rozmiary, związane $\mathrm{z}$ rozwojem współczesnych mu organizacji międzynarodowych. Organizacje o znaczeniu światowym i o szerokich kompetencjach, jak Organizacja Narodów Zjednoczonych (ONZ) wraz z jej organami wyspecjalizowanymi, regionalnymi o charakterze ponadpaństwowym, dotąd nieznanymi, jak Wspólnoty Europejskie (Wspólnota Europejska Węgla i Stali, Europejska Wspólnota Ekonomiczna, Wspólnota Europejska Energii Atomowej) wzbudzały poważne zainteresowanie Kościoła jako potęgi duchowej i Stolicy Apostolskiej, jako instytucji o charakterze międzynarodowym. Inspiracja szła niewatpliwie od samego Papieża dla stworzenia t. zw. „Małej Europy”, będącej w trakcie powstawania. To za czasów Piusa XII Stolica Apostolska wypracowała sposób relacji i współpracy z nimi, ostatecznie uściślony za Pontyfikatu Pawła VI.

W tej postawie wobec organizacji międzynarodowych za Piusa XII pojawiła się pewna nowość. Bowiem zainteresowania Stolicy Apostolskiej nie datują się od niego. Doktryna społeczna Kościoła domagała się już od jego poprzedników spoglądania z sympatią na takie instytucje, jak Stowarzyszenie Międzynarodowe dla prawnej ochrony robotników, przy którym Stolica Apostolska miała od początku swego reprezentanta (rok 1900) a przede wszystkim na Międzynarodową Organizację Pracy (OIT), powołaną do życia Traktatem Wersalskim, której statut, już w swej preambule był mocno związany z nauką społeczną Leona XIII. Nawet wierność socjalizmowi Alberta Thomasa, pierwszego dyrektora generalnego Międzynarodowego Biura Pracy nie przeszkadzała, aby Pius XI godził się chętnie na tę organizację i na nawiązanie z nią kontaktu. W roku 1931 w przesłaniu skierowanym właśnie do tego Papieża, z racji ogłoszenia przez niego encykliki „Ouadragesimo Anno", na rocznicę encykliki „Rerum Novarum” A. Thomas pisał on, że „Międzynarodowa Organizacja Pracy, gdy przedsięwzięła to ogromne zadanie, $\mathrm{z}$ ogromnym zapałem i pełna nadziei, była świadoma, że nie powstała spontanicznie, ale była owocem dawniejszych inicjatyw. Ziarno zostało rzucone na żyzną ziemię, troskliwie przygotowaną od lat przez robotników pełnych inicjatywy, szczególnie 
przez tych, którzy odwoływali się do encykliki „Rerum Novarum”1 . Od roku 1926, za zgodą Stolicy Apostolskiej, pomiędzy pracownikami sekretariatu Biura Międzynarodowego Pracy (BIT) znalazł się młody Jezuita André Arnou, a liczne organizacje chrześcijańskie międzynarodowe i państwowe były zapraszane do uczestnictwa w jego pracach ${ }^{2}$.

Na płaszczyźnie bardziej ogólnej, tam gdzie umiejscowiała się Liga Narodów powstała $\mathrm{w}$ roku 1920, stanowisko papiestwa było raczej bardziej powściagliwe. Od roku 1917 Benedykt XV wzywał do zmiany relacji międzynarodowych, które zastąpiłyby "siłę materialną armii”, "siłą moralną prawa”, przez redukcję zbrojeń i sąd rozjemczy obowiązkowy, należycie usankcjonowany $^{3}$. Niestety Liga Narodów tego nie zapewniała. Ale mimo to Benedyktowi XV przyświecała idea, że kiedyś taka organizacja powszechna zaistnieje. Pisał on, że jest rzeczą konieczna, aby wszystkie państwa, pozbyły się uprzedzeń wzajemnych i zjednoczyły się dla stworzenia jednego społeczeństwa, lepiej jeszcze, jednej rodziny, tak dla obrony ich wolności, jak i dla zachowania porządku społecznego, Narodom zjednoczonym w Lidze opartej na prawie chrześcijańskim Kościół będzie wiernym w użyczaniu swego aktywnego poparcia dla wszystkich przedsięwzięć inspirowanym przez sprawiedliwość i miłośćc ${ }^{4}$. Toteż w pierwszej swojej encyklice Pius XI wyrażał żal, że Liga Narodów, ta nowa instytucja międzynarodowa okazała się za słabą, aby ,narzucić wszystkim narodom pewien rodzaj kodeksu międzynarodowego, przystosowanego do obecnych czasów". Aby była analogiczną do tej, która istniała w średniowieczu, a była prawdziwa „społecznością narodów”, która nazywa się chrześcijaństwem ${ }^{5}$. Wszelka forma współpracy między Stolicą Apostolską i Liga Narodów oznaczała usunięcie poważnych trudności prawnych i psychologicznych. Tymczasem środowiska katolickie ujawniały często niedomówienia względem tej Organizacji, która jawiła się im jako mająca inspiracje socjalistyczne i masońskie ${ }^{6}$.

Wyraźny zwrot ku współpracy z organizacjami międzynarodowymi nastapił za pontyfikatu Piusa XII. Złożyło się na to wiele przyczyn. Przede wszystkim czynnik prawny. Od roku 1929 Traktaty Laterańskie dały Stolicy Apostolskiej w dziedzinie relacji międzynarodowych wolność działania, czego jej dotąd brakowało. Za reżimu tzw. „prawa gwarancji”, królestwo włoskie

\footnotetext{
${ }^{1} \mathrm{P}$. B e r t o li, Le Saint Siège et les organisations internationales, "Revue des Deux Mondes" (1961), s. 201.

${ }^{2}$ Pisał o tym m.in. A. A r n o u, L'Organisation Internationale du Travail et les catholiques, Paris 1933; A. L e R oy, Catholicisme social et organisation international du travail, Paris 1937; M. B a rbi er, L'Eglise Catholique et l'OIT. Un demi siècle de relations, Paris 1951; L. J. L e b r e t, Foi et développement, Paris 1972.

${ }^{3}$ Benedykt XV, Message aux peuples belligerants et à leurs chefs, z 1 sierpnia 1917.

${ }^{4}$ Benoit XV, Encyclique „Pacem Dei munus pulcherrimum” z 23 maja 1920.

${ }^{5} \mathrm{Na}$ temat nauczania Benedykta XV pisał R. A rés w swoim dziele L'Eglise catholique et l'organisation de la société internationale contemporaine (1939-1949), Montréâl 1949, ss. 17-99.

${ }^{6} \mathrm{~L} . \mathrm{Ch}$ e va ille r, C. L e fe bvre i R. Metz, Le droit et des institutions de l'Eglise catholique latine de la fin du XVIII siècle à 1979, [w:] Histoire du droit et des institutions de l'Eglise en Occident, red. G. De Bras, J. Gaudemet, t. 18, Paris 1982, s. 406.
} 
z obawy, aby nie została podniesiona tzw. „kwestia rzymska” przeciwstawiało się i to skutecznie, aby Stolica Apostolska brała udział w Konferencji Haskiej w roku 1899 a dotyczącej pokojowych uregulowań zatargów międzynarodowych. Podobnie w roku 1919 Benedykta XV pozostawiono na uboczu Konferencji Pokojowej w Wersalu. Ustanawiając Państwo Watykańskie Traktaty Lateraneńskie dostarczyły Stolicy Apostolskiej gwarancji i symbolu wyraźnej niezależności i niepodległości, co pozwoliło na uregulowanie stosunków z państwem włoskim. Przez to Traktaty Lateraneńskie pozwoliły na poważna ewolucję w relacjach między Kościołem i światem"7.

Tu jawi się pytanie, jak ta ewolucja mogła uregulować relacje Stolicy Apostolskiej z organizacjami międzynarodowymi. Większość znawców tej epoki uważa, że osobowość Piusa XII bardzo wyraźnie na nich zaważyła. Trzeba bowiem przypomnieć, że był to Papież dyplomata. Wszedłszy do Sekretariatu Stanu jeszcze za Leona XIII, w roku 1901, mając zaledwie dwadzieścia pięć lat, młody ks. Eugenio Pacelli, bardzo szybko awansował na odpowiedzialne stanowisko podsekretarza w roku 1912 w Kongregacji dla Spraw Kościelnych Nadzwyczajnych a w roku 1914 na sekretarza. Do niego należało m.in., tuż przed pierwszą wojną światową, przygotowanie konkordatu z Serbią. Mianowany przez Benedykta XV nuncjuszem apostolskim w Monachium w roku 1917, miał w tym samym roku negocjować z Imperiami centralnymi, będącymi w stanie wojny, propozycje pokoju i kompromisu bezskutecznie proponowanego stronom walczącym. Następnie wzią udział w ostatniej fazie przygotowań do konkordatu z Bawarią i z Prusami. Pius XI mianował go kardynałem 16 grudnia 1929 roku a wkrótce postawił go na czele administracji apostolskiej po kardynale Piotrze Gasparim. Wybrany papieżem 2 marca 1939 Pius XII pozostał $\mathrm{w}$ dalszym ciagu dyplomata. To nie przypadkiem po śmierci Kard. Luigi Maglione w roku 1944 pozostawił Sekretariat Stanu nie obsadzony. Dwaj podsekretarze Giovanni Baptista Montini i Domenico Tardini podzielili między siebie obowiązki, które pozostały, ogólnie rzecz biorąc, w gestii papieskiej.

Wydarzenia, jakie nastapiły a mianowicie wybuch drugiej wojny światowej, w sześć miesięcy po wyborze Piusa XII na Stolicę Piotrową i niepokoje po drugiej wojnie światowej uczyniły papieskie działania szczególnie delikatnymi. Wielokrotnie popychały tego Papieża do zajęcia stanowiska wobec organizacji i reorganizacji społeczeństwa międzynarodowego. Wyraźnie obecna w świecie Stolica Apostolska nie mogła zapomnieć o doprecyzowaniu nauki Kościoła w tej dziedzinie. Wymagał tego czas, w jakim działała. Ten zaś był wciąż bardzo skomplikowany. „Zimna wojna”, jaka się pojawiła po drugiej wojnie światowej, nie upraszczała problemu. Wszelkie nadzieje na uniwersalizm wydawały się być mrzonką. Przynajmniej te, które w swej wizji tradycyjnej mieli papieże. Miał ją także Pius XI. Nie osłabiała ona jednak wsparcia Watykanu dla stworzenia struktur europejskich, które przybrałyby jednak inną logikę.

${ }^{7} \mathrm{Ph}$. Levilla in, F. C. Ug in et, Le Vatican ou des frontiéres de la grâce, Paris 
PIUS XII I ORGANIZACJA SPOLECZENSTWA MIĘ Z Y NARODOWEGO

Gdy pragnie się oceniać uczestnictwo Stolicy Apostolskiej, jako takiej, czy ewentualnie organu Państwa Watykańskiego w aktywności organizacji międzynarodowych $w$ tamtej epoce ${ }^{8}$. Trzeba od razu rozróżnić $w$ nauczaniu Piusa XII doktrynę tzw. nauczania zawartą w encyklikach, listach i konstytucjach apostolskich, w apelach, przemówieniach i jego alokucjach i fakty porządku instytucjonalnego.

Pius XII nie czekał na zakończenie wojny, aby ujawnić swoje stanowisko Kościoła dotyczące rekonstrukcji społeczeństwa międzynarodowego. Zaledwie wybrany papieżem, położył nacisk na pozytywny wpływ na utrzymanie pokoju, jaki mogłaby zapewnić odnowiona międzynarodowa organizacja. Jego pierwsza encyklika „Summi Pontificatus” z 20 października 1939 podkreślała konieczność ustalenia „nowego porządku w świecie”, który wyrwalby się "spod lotnego piasku zmieniających się i krótkotrwałych reguł, pozostawionych decyzji egoizmu zbiorowego, czy indywidualnego". Zaś 10 listopada 1939 w przemówieniu wezwał do stworzenia „organizacji, która będzie respektowała prawa Boskie i będzie mogła zapewnić wzajemną niezależność państw wielkich i małych, narzucić wierność umowom lojalnie podjętym i zachować, poprzez wysiłek każdego dla dobra wszystkich, zdrową wolność i godność osoby ludzkiej"'. W kilka tygodni później w przemówieniu na Boże Narodzenie wskazał jako "na fundamenty pokoju sprawiedliwego i trwałego", na „utworzenie instytucji prawnych dla zagwarantowania lojalnego i wiernego stosowania konwencji a w razie potrzeby, przejrzenia ich i skorygowania ${ }^{10}$. Papieskie deklaracje mnożyły się. Wskazywał $\mathrm{w}$ nich na potrzebę realizacji propozycji światowej organizacji, co zostało przyjęte 7 października 1944 roku w Dumbarton Oaks.

Czy te propozycje z roku 1944 i Karta Narodów Zjednoczonych, podpisana w San Francisco 26 czerwca 1945 roku odpowiadały myślom Piusa XII? $\mathrm{Z}$ pewnością nie. W tym czasie snuł on refleksję nad słynnym traktatem dotyczącym prawa naturalnego, jezuity włoskiego, L. Taparelli d' Azeglio. Stąd

${ }^{8}$ Literatura dotycząca tego problemu jest obfita. Obok cytowanego już dzieła R. Arèsa, P. Bertoliego i L. Chevaillera wymienić trzeba: R. B o s c, La société internationale et l'Eglise. Sociologie et morale des relations internationales, Paris 1961; L. C a r d in a le, Le Saint Siège et la diplomatie, Paris-Toumai 1962; R. C o st e, Morale internationale, Paris 1964 a przede wszystkim jego Le problème du droit de la guerre dans la pensée de Pie XII, Paris 1962; R. A. Graham, Vatican Diplomacy, Princeton 1959; H. Fr. K o e ck, Die Völkerrechtliche Stellung des Heiligen Stuhls, Berlin 1975 (z bogatą bibliografia); J. L u c i e n - B r u n, Le Saint Siège et les institutions internationales, Annuaire français de droit international (1964), s. 536; F. R u s s o, Le Saint Siège et les organisations internationales, „Etudes” (1976) nr 1 (345), s. 15. Nadto: G. G o n n e 11 a, The Papacy and World Peace, London 1945; A. G u e r r y, L'Eglise et la communauté des peuples, Paris 1958; N. Nuccitelli, Le fondement juridique des rapports diplomatiques entre le Saint Siège et les Nations Unies, Paris 1956; A. d e S o r a s, Les directives de S.S. Pie XII pour l'organisation de la paix internationale, Paris 1945.

${ }^{9}$ Pie XII, Documents Pontificaux. 1939, t. 1, Saint Maurice 1961, s. 330.

${ }^{10}$ Tamże, s. 383-384. 
oczekiwał przyjęcia dla dobra społeczności międzynarodowej doktryny tradycyjnej Kościoła o społeczeństwie politycznym ${ }^{11}$. Zawiera ona prawo solidarności powszechnej, którego nie uznawali zwolenicy nacjonalizmów i totalitaryzmów oraz, ogólnie rzecz biorąc, wszyscy ci, którzy uważali państwo za społeczeństwo doskonałe, wystarczające samo sobie i w pełni suwerenne. W epoce współczesnej jedynie organizacja polityczna międzynarodowa mogłaby pretendować do tytułu "societas naturalis perfecta", którą św. Tomasz z Akwinu nazywał civitas. Ludy tworzyły wtedy jedną wspólnotę naturalna, której Bóg zlecił organizowanie się w społeczność na zasadach porządku i sprawiedliwości, dla dobra wspólnego międzynarodowego. Dla zrealizowania tego celu, najwyższa władza, czerpiąc swe kompetencje nie z kontraktu czy delegacji, ale z własnego prawa, powinna stanowić rodzaj rządu światowego, przeznaczonego dla służenia wszystkim państwom w rzeczach realnych i efektywnych ${ }^{12}$, zaopatrzonego w możliwość podjęcia wszystkich możliwości dla zapewnienia pokoju międzynarodowego ${ }^{13}$.

Karta Narodów Zjednoczonych miała niewielkie ambicje. Poza tym ta nowa Organizacja nie była ani powszechną ani obowiązkową. Pozostawiała ona państwom dziedziny zarezerwowane ich wyłącznej decyzji. Dawała także stałym członkom Rady Bezpieczeństwa, tzn. mocarstwom prawo weta, które wkrótce uległo degeneracji i paraliżowało wszystkie ważniejsze przedsięwzięcia. Nic dziwnego, że Pius XII wypowiadał otwarcie od roku 1947 swe niezadowolenie. Żaden przewidujący i zdrowo osądzający umysł, pisał, po rozczarowaniach i wypowiedziach co najmniej upokarzających, nie będzie uważał tej światowej trybuny, tzn. ONZ, za wystarczająca ${ }^{14}$. Mimo to daleki był od namawiania do odwracania się od niej. „Żaden $\mathrm{z}$ tych, którzy pragną walczyć o godny pokój, nie powinien odrzucać posługiwania się tą możliwością (ONZ), mimo jej ograniczeń a to dla obudzenia sumienia świata tam, gdzie dzieje się krzywda i toczy się wojna"15. Jednocześnie nie przestawał wzywać katolików do uczestnictwa w życiu międzynarodowym i w działalności organizacji międzynarodowych. Dla niego jest to ich zadanie misyjne, bowiem „żadna grupa ludzka nie ma tak pozytywnych warunków, jak Kościół w swych wymiarach i głębi, i takiego przeznaczenia międzynarodowego"16. To prawda, że Pius XII myślał przede wszystkim o organizacjach katolickich międzynarodowych, które za jego pontyfikatu, mnożyły się i wzmacniały swoje struktury.

${ }^{11}$ Tytuł traktatu w języku francuskim brzmi: Essai théorique de droit naturel basé sur les faits, Tournai 1857. - $O$ autorze tego traktatu pisał Robert Jacquin: „Un frère de Massimo d'Azeglio. Le père Luigi Taparelli d'Azeglio (1793-1862). Sa vie, son action et son oeuvre, (Paris 1943). R Bosc uważa, że nowość jego doktryny zawiera się w tym przeniesieniu.

${ }^{12}$ Pie XII, Documents Pontificaux. 1944, t. 6, Saint Maurice 1963, ss. 242-256.

${ }^{13}$ Na Boże Narodzenie Papież mówil, że organizacja „powinna mieć prawo i władzę do przeciwstawienia się każdej interwencji militarnej jednego kraju w drugim, pod jakimkolwiek pretekstem". - Pie XII, Documents Pontificaux. 1956, t. 18, Saint Maurice 1958, ss. 749-769.

${ }^{14}$ Pie XII, Documents Pontificaux. 1947, t. 9, Saint Maurice 1961, s. 317.

${ }^{15}$ J. P. M a c h elo n, Pie XII. L'Europe et les institutions internationales, [w:] Pie XII et la cité. La pensée et l'action politique de Pie XII, Saint-Cénére 1988, ss. 203 i ns.

${ }^{16}$ Pie XII, Documents Pontificaux. 1957, t. 19, Saint Maurice 1959, s. 626. 
Niektóre z nich cieszyły się statusem doradczym dla instytucji związanych z Organizacją Narodów Zjednoczonych ${ }^{17}$. Nie wykluczał jednak takich organizacji międzynarodowych, które respektowały „w teorii i w praktyce prawa naturalne"18. Osąd Piusa XII o instytucjach wyspecjalizowanych Narodów Zjednoczonych, był zresztą przychylniejszy niż do ONZ a zatem do Światowej Organizacji Zdrowia, do Organizacji Narodów do Spraw kultury, oświaty i nauki (UNESCO), a przede wszystkim do Międzynarodowej Organizacji Pracy oraz Organizacji Wyżywienia i Rolnictwa (FAO) ${ }^{19}$. Natomiast innym problemem było, czy Stolica Apostolska mogłaby bezpośrednio działać w organizacjach międzynarodowych.

Obecność Stolicy Apostolskiej w poważnych organizacjach międzynarodowych miała za sobą istotne racje, wypływające $\mathrm{z}$ ogólnej jej funkcji ożywiania duchowego, ciążącej na Kościele, z jej naturalnej roli bycia organem jednoczącym oraz $\mathrm{z}$ częściowej zbieżności jej misji w porządku ziemskim $\mathrm{z}$ wartościami głoszonymi przez $\mathrm{ONZ}$, polepszenia materialnego i duchowego warunków człowieka i obrony jego praw, m.in. poszukiwania lepszego zrozumienia wzajemnego między narodami i państwami. Na płaszczyźnie praktycznej Kościół jest zresztą zobowiązany do współpracy „w terenie” (m.in. w Trzecim świecie) $\mathrm{z}$ organizacjami międzynarodowymi a nie tylko $\mathrm{z}$ organizacjami pozarządowymi (ONG), o charakterze społecznym i kulturalnym, których pole działalności zostało na nowo określone ${ }^{20}$. Idea uczestnictwa Stolicy Apostolskiej w działalności organizacji międzynarodowych jawiła się jako zbieżna $\mathrm{z}$ uniwersalnością Kościoła i z charakterem istotnie ponadnarodowym dyplomacji papieskiej, co Pius XII silnie podkreślał. „Kościół katolicki, którego centrum jest Rzym, jest ponadnarodowym ze swej istoty. Nie przynależy on i nie może przynależeć do takiego lub innego państwa czy narodu ściślej niż do innego. Nie jest on i nie może być obcym w żadnym miejscu. Żyje on, a przynajmniej powinien żyć, wśród wszystkich narodów"21.

Trzeba jednak mieć świadomość, że pozycja Stolicy Apostolskiej była szczególna, gdy chodzi o powiązania międzynarodowe. Traktat Lateraneński przewidywał, że zachowa ona naturalność wobec mocarstw politycznych. „Stolica Apostolska, w tym, co dotyczy suwerenności, jaka jej przynależy, także w dziedzinie międzynarodowej, deklaruje, że pozostaje i pozostanie niezależną $\mathrm{w}$ sprawach ziemskich, $\mathrm{w}$ relacjach $\mathrm{z}$ innymi państwami $\mathrm{i}$ organiza-

${ }^{17}$ R. B o s c, La societé..., ss. 364 i ns.; J. L u c i e n - B r u n, La Saint Siège et les institutions..., S. 541-542.

${ }^{18}$ Tamże, s. 203.

19 J. L u c i e n - B r u n, La Saint Siège et les institutions..., s. 538, przyp. 4; R. B o s c, La societé..., s. 383, przyp. 1.

${ }^{20} \mathrm{P}$. B e r to $1 \mathrm{i}$, La Saint Siège et les organisations..., ss. 198-201.

${ }^{21}$ Pie XII, Documents Pontificaux. 1944, t. 6, Saint Maurice 1963, s. 97. 
cjami międzynarodowymi powołanymi dla tego celu, o ile strony w sprawach spornych nie zaapelują jednocześnie o jej misję pokojową, rezerwując sobie w każdym przypadku swą siłę moralną i duchową

Pius XII interpretował tę zasadę w sensie ścisłej neutralności. „Kościół, głosił, nie chce opowiadać się za jedną lub drugą szczególną i konkretną forma, przez które różne narody czy państwa próbują rozwiązać własne a trudne problemy organizacji wewnętrznej, jak i współpracę międzynarodową o ile te rozwiązania respektują prawo Boże $e^{23}$. Nieco później dodawał, że „Kościół pozostaje neutralny, albo jeszcze lepiej, gdyż to określenie jest zbyt bierne i niejasne, bezstronny i niezależny. Stolica Apostolska nie pozwala się opanować przez żadne mocarstwo czy grupę mocarstw politycznych, nawet jeśli po tysiąckroć głoszą one co innego",24.

Ta pacceliańska wola pozostawania na uboczu problemów bezpośrednio politycznych wyjaśnia różnorodność form i sposobów, jakie przybrały relacje Stolicy Apostolskiej z organizacjami międzynarodowymi w latach po drugiej wojnie światowej. Toteż uczestnictwo w Organizacji Narodów Zjednoczonych, w tym forum międzynarodowym o charakterze politycznym, na terenie którego ścierały się różne ideologie było dla niej nie do przyjęcia w tym czasie. Ale pozostając poza ONZ Stolica Apostolska utrzymywała relacje oficjalne z nią i przyłączyła się do niektórych z jej działań. W przeciwieństwie do tego, co niektóre dokumenty oficjalne ONZ głosiły, to nie Państwo Watykańskie ale Stolica Apostolska brała udział w rozmowach z tą Organizacja, tzn. centralny rząd Kościoła. To nieporozumienie zostało rozwiane w październiku 1957 roku poprzez wymianę not między Sekretariatem Stanu i Dag Hammarskjödem, sekretarzem generalnym $O N Z^{25}$. Od roku 1956 zjawiła się reprezentacja Stolicy Apostolskiej w Radzie Ekonomicznej i Społecznej Narodów Zjednoczonych w Genewie.

Pierwsze kontakty między Stolicą Apostolską i Narodami Zjednoczonymi dotyczyły dziedziny humanitarnej, opieki nad uciekinierami. Pius XII wyrażał swe zainteresowanie wobec Administracji Narodów Zjednoczonych dla bezpieczeństwa i odbudowy (UNRRA), stworzonej w roku 1943 i dla Międzynarodowej Organizacji dla uciekinierów (OIR), która była jedną z instytucji specjalistycznych Narodów Zjednoczonych a która została zastappiona w roku 1952 przez Wysokiego Komisarza Narodów Zjednoczonych dla uchodźców. Od początku Stolica Apostolska przynależała do Komitetu Wykonawczego programu Wysokiego Komisariatu. Była także obserwatorem przy pracach Komitetu Międzynarodowego dla migracji europejskich (CIME).

Stolica Apostolska utrzymywała zresztą za czasów Piusa XII relacje organịczne, czy współpracowała mniej czy bardziej ściśle $\mathrm{z}$ wielu instytucjami wyspecjalizowanymi ONZ (w sensie artykułu 57 Karty), albo z innymi organi-

${ }^{22}$ Traité de Lateran, Paris 1935, article 24, par. 1.

${ }^{23}$ Pie XII, Documents Pontificaux. 1956, t. 18, Saint Maurice 1958.

${ }^{24}$ Pie XII, Documents Pontificaux. 1953, t. 15, Saint Maurice 1957, s. 186; I. C a r d i n a l e, La Saint Siège et la diplomatie..., s. 77.

${ }^{25} \mathrm{~L} . \mathrm{C}$ h e v a ill er et alii, Le droit..., s. 408. 
zacjami o charakterze społecznym, kulturalnym, naukowym i technicznym. Trzeba wymienić na pierwszym miejscu Organizację Międzynarodowa Pracy (OIT), którą jak już wspomniano, łączyły liczne więzy z różnymi organizacjami katolickimi. Jednak do roku 1967 Stolica Apostolska nie miała z nią oficjalnych relacji. Natomiast, choć nie figurowała ona jako członek, miała ona od roku 1948 stałego obserwatora akredytowanego przy Organizacji do Spraw Wyżywienia (FAO). Czwarta sesja Konferencji FAO (Waszyngton listopad 1948) przyjęła Stolicę Apostolską do Zgromadzenia czterdziestu jeden głosami, przy jednym sprzeciwie i jednym wstrzymującym się. W ten sam sposób była ona reprezentowana przy Swiatowej Organizacji Zdrowia (OMS) od 1949 roku. Została ona oficjalnie zaproszona do uczestnictwa w drugim Zgromadzeniu Światowym OMS w Rzymie, w czerwcu 1949 roku, w UNESCO od roku 1952. Nominacja pierwszego stałego obserwatora Stolicy Apostolskiej przy UNESCO, którym był i pozostał za Piusa XII nuncjusz w Paryżu abp Angelo Giuseppe Roncali, późniejszy Papież Jan XXIII, przyszła 28 maja 1952 roku, gdy organizacja przyjęła zasadę uczestnictwa w jej pracach obserwatorów stałych spoza państw członkowskich. Poprzedziła ją od początków istnienia tej instytucji, pewna forma współpracy. W roku 1946 delegacja złożona $\mathrm{z}$ trzech członków, delegowanych przez arcybiskupa Paryża a kierowana przez bpa Blanchet, rektora Instytutu Katolickiego, uczestniczyła oficjalnie w pierwszej konferencji generalnej UNESCO. Później pozostawiła ona miejsce „komitetowi katolickiemu międzynarodowemu koordynacji”, nazywanemu także „komisją watykańską przy UNESCO”, której kierujący byli mianowani przez Stolicę Apostolską a członkowie przez hierarchie międzynarodowe, czy katolickie organizacje międzynarodowe ${ }^{26}$.

Relacje oficjalne z tymi organizacjami pozwoliły Stolicy Apostolskiej uczestniczyć aktywnie w ich pracach, szczególnie w dziedzinie kulturalnej. Jednak jest rzeczą jasną że uczestnictwo nie znaczyło iż Stolica Apostolska zgadzała się ze wszystkim. Kwestia regulacji urodzin dostarcza przykładu wyraźnego braku zgody. W sposób ogólny, na początku lat pięćdziesiątych Watykan sądził, że Światowa Organizacja Zdrowia (OMS) i UNESCO stanowiły poważne niebezpieczeństwo dla dzieła misyjnego Kościoła, wbrew głoszeniu neutralności, w dziedzinie moralnej i religijnej ${ }^{27}$.

Relacje Stolicy Apostolskiej byly ściślejsze $\mathrm{z}$ innymi organizacjami międzynarodowymi o charakterze wyłącznie technicznym czy naukowym i o przedmiocie bardziej ograniczonym. W roku 1957 nawiazała ona relacje pomiędzy członkami założycielami Agencji Międzynarodowej Energii Atomowej (AIEA). Jako takie, państwo Watykańskie było członkiem pewnej liczby organizacji, spadkobierców starych „unii administracyjnych”, czy powołanych do życia później a mianowicie Ogólnoświatowej Unii Pocztowej (UPU), Międzynarodowej Unii Telekomunikacyjnej (UIT), Międzynarodowej Unii dla protekcji dziedzictwa literackiego i artystycznego (Union de Bern), Międzyna-

\footnotetext{
${ }^{26}$ Tamże, s. 411.

${ }^{27}$ Tamże, s. 412 i 420.
} 
rodowej Unii dla protekcji własności przemysłowej (Union de Paris), Światowej Organizacji Meteorologicznej (OMM), Organizacji Lotnictwa Cywilnego Międzynarodowego (OACI), nie wymieniając innych, pomniejszych. Wymienione zostały tylko organizacje międzynarodowe stricto sensu, posiadające charakter stały, które przynależały do państwa oraz organizacje o charakterze międzynarodowym. Trzebaby jeszcze wskazać na uczestnictwo Stolicy Apostolskiej w różnych konferencjach międzynarodowych, organizowanych po drugiej wojnie światowej przez ONZ oraz jej działania w kierownictwie organizacji pozarządowych (ONG), szczególnie Międzynarodowego Czerwonego Krzyża. Jest ona także sygnatariuszem konwencji w Genewie w roku 1949, oraz Konwencji Haskiej z 14 maja 1954 roku a dotyczącej protekcji dóbr kulturalnych w wypadku konfliktu zbrojnego.

\section{PIUS XII WOBEC PROBLEMU ZJEDNOCZENIA EUROPY}

Pius XII opowiadał się za konstrukcją zjednoczonej Europy. Tu jawi się pytanie, czy nie ma sprzeczności między zasadami uniwersalistycznymi, relatywnymi do organizacji społeczeństwa międzynarodowego a wsparciem $\mathrm{Pa}$ pieża dla zjednoczonej Europy. Na ten temat pojawiło się wiele publikacji ${ }^{28}$.

Nauczanie Piusa XII precyzowało się powoli i stopniowo. Gen. Ch. de Gaulle pisał, że Papież myślał w lecie roku 1944, iż ,tylko unia ścisła krajów europejskich inspirowana przez katolicyzm tzn. Niemcy, Francję, Włochy, Hiszpanię, Belgię, Portugalię, może pokonać komunizm”29. Jednak dopiero w roku 1948 ujawnił on po raz pierwszy swoje stanowisko publicznie. W kilka dni po wysłaniu osobistego reprezentanta na Kongres Europy w Hadze (maj 1948), wypowiedział się na rzecz „unii europejskiej” ( 2 czerwca). 11 listopada wobec delegatów Unii Europejskiej federalistów, kładł nacisk na nagłą potrzebę, „aby wielkie państwa kontynentu, o długiej historii, które znały chwałę i mocarstwowość" zapomniały o ich historycznej wielkości i opowiedziały się za wyższą jednością polityczną i ekonomiczną ${ }^{30}$.

Zaproszenie było jasne i wielokrotnie powtarzane. W roku 1952 Papież zachęcał do „wysiłku rządy państw. Pod presją konieczności, która domaga się jednoczenia się Europy powinny one realizować cele polityki, która zakładałaby nowe spojrzenie na relacje narodu do narodu" (13 września) ${ }^{31}$. W roku następnym (1953) Pius XII ukazywał „ducha europejskiego ,jako cel pierwszorzędny, bez czego nic solidnego nie może powstać" $(15 \text { marca })^{32}$. W kilka miesięcy później (24 grudnia 1953) mówił, że Europa powinna realizować unię kontynentalną między krajami ${ }^{33}$.

${ }^{28}$ M.in. J.-M. M a y e u r, Pie XII et l'Europe, „Relations Internationales" (1981) nr 1 (28), ss. 413-425, który podaje bogatą bibliografię.

29 Tamże, s. 417.

${ }^{30}$ Pie XII, Documents Pontificaux. 1948, t. 10, Saint Maurice 1950, ss. 402-407.

${ }^{31}$ Pie XII, Documents Pontificaux. 1952, t. 14, Saint Maurice 1955, ss. 416 i ns.

${ }^{32}$ Tamże, t. 15, s. 77 i ns.

${ }^{33}$ Tamże, s. 653-654. 
Wyrażenie „Europa kontynentalna” jest bogate w treść. Zbliża się ono bardzo mocne do „Europy sześciu” (Francja, Niemcy, Anglia, Włochy, Hiszpania Portugalia i Belgia). Była to także Europa ponadnarodowa, jakiej Anglia sobie nie życzyła, odrzucająca wizję klasyczną i ścisłą suwerenności państwowej.

Pius XII z radością przyjmował wiadomość o powstałej w roku 1950 Europejskiej wspólnocie Węgla i Stali (CECA), zaproponowanej przez R. Schumana. Witał ją jako odważną ${ }^{34}$. Podkreślał korzyści ekonomiczne, społeczne a nawet duchowe. „Kraje europejskie, uważał on, które przyjęły zasadę częściowego ograniczenia ich suwerenności na rzecz organizmu ponadpaństwowego, wchodzą, trzeba w to wierzyć, na drogę zbawczą. Stąd może zrodzić się dla nich i dla Europy życie nowe we wszystkich dziedzinach, ubogacenie nie tylko ekonomiczne i kulturalne, ale także duchowe i religijne"35. Nieco wcześniej (13 czerwca 1957) wyrażając do uczestników Kongresu Europy, któremu przewodniczył $\mathrm{R}$. Schuman, radość z postępu w kierunku pełnej realizacji idei europejskiej wypowiedział znamienne słowa: „Tak dhugo jak idea ta nie wcieli się $w$ instytucje społeczne, oparte o własny i niezależny autorytet rządów państwowych, i to w całej pełni, trzeba ja uważać jako ideał piękny ale mniej czy więcej niedostępny. Otóż w roku 1952 Parlamenty sześciu krajów Europy zachodniej zgodziły się na stworzenie Wspólnoty Europejskiej Węgla i Stali (CECA), której rezultaty jawią się obecnie jako skuteczne na płaszczyźnie ekonomicznej i społecznej”36.

Z tej samej racji projekt Wspólnej Europejskiej Obrony (CED) był popierany przez Watykan a jego porażka mocno krytykowana. Pius XII wskazywał na odradzający się nacjonalizm jako na przyczynę braku zgody na tę Wspólnote $^{37}$. Wielu, m. in. R. Schuman ${ }^{38}$, znało sympatie Papieża dla idei federalistycznych. Do końca swego Pontyfikatu opowiadał się on za federalizmem europejskim. Uczynił to $\mathrm{m}$. in. wobec uczestników III Kongresu sekcji włoskiej Rady Wspólnot Europy. „Głos autonomii lokalnych, ich aspiracje i ich troska stanowi element jednocześnie stymulujący i utrzymujący równowage w wypracowywaniu jedności federacji europejskiej, za którą trwają poszukiwania. Wasza organizacja może, dzięki wielorakości jej centrów działania, propagować skutecznie ideę federalizmu i przez to przyspieszać jej realizację. Trzeba mieć nadzieję, że decyzje rządowe zostaną wsparte przez opinię publiczną. (...) Trzeba zbudować w Europie szeroki federalizm, który wypływa z zasad presonalizmu"39, rozumianego jako zjednoczona Europa.

Nadzieja wzrosła znowu na początku roku 1955. Pius XII z uwaga obserwował opracowywanie Traktatów Rzymskich. Uważał też za bardzo pozytywne stworzenie Euroatomu i Europejskiej Wspólnoty Ekonomicznej (CEE).

\footnotetext{
${ }^{34} \mathrm{P}$ i e XII, Documents Pontificaux. 1957, t. 19, Saint Maurice 1959, s. 185.

${ }^{35}$ Tamże, s. 293.

${ }^{36}$ Tamże, s. 389.

${ }^{37}$ J.-M. M a y e u r, Pie XII..., s. 419.

${ }^{38}$ R. P o i t e v i n, Robert Schuman, l'homme d'état (1886-1963), Paris 1986, s. 414.

${ }^{39} \mathrm{P}$ i e XII, Documents Pontificaux. 1957, t. 14, Saint Maurice 1959, s. 357.
} 
Wytykał, to prawda, że z punktu widzenia ponadpaństwowego, tzn. gdy chodzi o ,utworzenie europejskiego autorytetu politycznego, posiadającego prawdziwą władzę, która ma własną odpowiedzialność", Europejska Wspólnota Ekonomiczna (CEE) posiada pewne ograniczenia w odniesieniu do Europejskiej Wspólnoty Węgla i Stali (CECA) i że „ta nowa wspólnota jest ograniczona w dziedzinie ekonomii”, ale dodawał, że „może ona prowadzić, przez poszerzenie pola swego działania, do umocnienia między krajami członkowskimi świadomości ich wspólnych korzeni, przede wszystkim na płaszczyźnie materialnej, bez wattpienia, ale jeśli sukces odpowie na oczekiwania, może następnie rozciagnąć się także na sektory, które będą bardziej angażować wartości duchowe i moralne"40.

W dniu podpisania Traktatów Rzymskich (25 marca 1957) Radio Watykańskie potwierdziło, że „droga, na jakiej angażują się obecnie kraje europejskie, dążyć będzie z konieczności do późniejszego zacieśnienia ich relacji, aż do solidarności idącej poza ekonomię,"41.

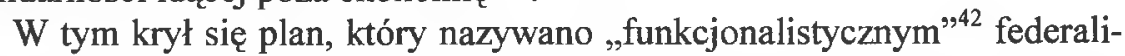
stów roztropnych, którzy redagowali traktat Europejskiej Wspólnoty Ekonomicznej (CEE) i ściśle określona wola kierownictwa europejskich partii chrześcijańskich demokratów R. Schumana, K. Adenauera i A. de Gasperi.

\section{KRYTYKA KONCEPCJI CHRZEŚCIJAŃSKICH DEMOKRATÓW ZJEDNOCZONEJ EUROPY}

Od samego początku pojawiła się krytyka koncepcji Zjednoczonej Europy, jaką miał R. Schuman, K. Adenauer i A. de Gasperi, popieranej przez Piusa XII. V. Auriol, socjalista, zarzucał jej twórcom, że oddali się w ręce Papieża opanowanego ideą antykomunizmu, filogermanizmu i ideą małej Euro$\mathrm{py}^{43}$. V. Auriol, prezydent Francji w latach tworzenia się CECA uważał, że Kościół zawarł potrójne przymierze: z K. Adenauerem, R. Schumanem i A. de Gasperi i dodawał, że są to „trzej tonsuraci pod jedną piuską (papieska)”. Natomiast socjalistyczny minister R. Lacoste na Kongresie partii socjalistycznej SFIO (maj 1954) mówił o „Europie renańskiej, którą czuć jednocześnie wodą święconą $\mathrm{i}$ dymem wielkich pieców’44. Zgodnie z tym mitem R. Schuman Lotaryńczyk, K. Adenauer Renańczyk i A. de Gasperi Trydentczyk, wszyscy trzej to ludzie gromnic, katolicy i germanofoni, którzy od swej młodości mieli związać się, aby służyć interesom czarnej międzynarodówki, prowadzeni w polityce europejskiej przez Watykan. Mimo pozoru prawdy, jaką nadawała tej tezie legendarna przyjaźń, twierdzenie to było fałszywe. René Lejeune twierdził, że w roku $1954 \mathrm{~K}$. Adenauer miał mu powiedzieć, że nie ma

${ }^{40}$ Pie XII, Documents Pontificaux. 1957, t. 19, Saint Maurice 1959.

${ }^{41} \mathrm{~L}$. C h e vai 11 e r et alii, Le droit..., s. 411.

${ }^{42} \mathrm{O}$ funkcjonalizmie jako teorii integracji europejskiej pisał E. B. Ha a s, The Uniting of Europe. Political, social and economic forces (1950-1957), London 1958.

${ }^{43}$ J.-M. M a y e u r, Pie XII..., s. 422.

${ }^{44}$ Tamże, por. J. P. M a c h e l o n, Pie XII. Le Europe..., s. 216. 
w Niemczech żadnego polityka niemieckiego, z którym byłby tak związany, jak $z$ R. Schumanem ${ }^{45}$. K. Adenauer i R. Schuman nigdy nie spotkali sie przed rokiem 1948. K. Adenauer sytuował ich pierwsze spotkanie na październik $1948 \mathrm{roku}^{46}$, R. Schuman zaś na sierpień 1949 roku $^{47}$. Gdy chodzi o ideę Europy tzw. Watykańskiej, która nie podobała się we Francji nawet niektórym środowiskom katolickim ${ }^{48}$, nie miała ona żadnych rzeczowych podstaw. Pius XII nie mówił nigdy o Europie demokracji chrześcijańskich, ale o Europie chrześcijańskiej. Dla niego ideałem była Europa. Teksty jego przemówień nawiązują wyraźnie do świętego Benedykta, „prawdziwego Ojca Europy” i do chrześcijaństwa średniowiecznego. Federalistom, pielgrzymom Pax Christi, członkom Kolegium Europy przypominał o cnotach i o ich skuteczności, domagając się „uznania praw Bożych a przynajmniej prawa naturalnego czyli podstawy, na której opierają się prawa człowieka"49.

Trzeba dodać, że dla Papieża, najwyższego Pasterza Kościoła powszechnego Europa nie identyfikuje się z kultura, czy z cywilizacją europejska, ani też tym bardziej z ideologią świata liberalnego. Chociaż potępiał komunizm totalitarny, nie wzywał nigdy do krucjaty przeciwko Europie komunistycznej, bo była ona prowadzona, jego zdaniem, do liberalizmu, który w jego oczach był źródłem współczesnego totalitaryzmu ${ }^{50}$. Odrzucał ideę identyfikacji Europy chrześcijańskiej z tą, którą premier Francji Georges Bidault nazywał „Europa wolności”s1. Jego wsparcie dla integracji europejskiej nie opierało się na wyborach ideologicznych, ale na koniecznościach innego porządku, który był daleki od łączności z orientacjami polityków demokratów chrześcijańskich i które nie opierało się na ograniczeniu jej do „Małej Europy”.

Te konieczności nie powinny być odłączne od już znanej troski o organizacje międzynarodowe. Opowiadając się za jednością Europy Pius XII nie przestawał pracować na rzecz przemiany atmosfery $\mathrm{w}$ relacjach międzynarodowych na rzecz ludów i pokoju. Jego celem ostatecznym pozostawała budowa wspólnoty światowej, opartej na zasadach prawa naturalnego. Aktywna aprobata dawana budowie Europy miała na celu przekroczenie etapu, stopnia na drodze, która w czasach powojennych jawiła się jako podwójnie długa i kręta.

${ }^{45} \mathrm{R} . \mathrm{L}$ e j e u n e, Robert Schuman. Une âme pour l'Europe, Paris 1986, s. 113.

${ }^{46} \mathrm{~K}$. A d e n a u e r, Memoires 1945-1953, Paris 1965, s. 298.

${ }^{47}$ R. S c h u m a n, Pour l'Europe, Paris 1964, s. 93; por. J. W a h1, Robert Schuman. Ojciec Europy, Gliwice [b.r.w.]

${ }_{48}$ J. M. M a y e u r, Pie XII..., ss. 423 i ns.

${ }^{49} \mathrm{P}$ i e XII, Documents Pontificaux. 1948, Saint Maurice 1958, s. 218

${ }^{50}$ J. M. M a y e u r, Pie XII..., ss. 420 i ns.

${ }^{51} \mathrm{P}$. H. T e itg e $\mathrm{n}$, Droit institutionnel communautaire. Structures et fonctionnement des Communautés européennes, t. 1, Paris 1977, s. 1. 